\section{CONFERENCE EVENT}

Thursday evening Watch our web site 〈http: //www.trail.com/asms/> and the spring issue of the Spectaker for details about our festive Thursday evening conference event.

\section{AWARD PRESENTATIONS AND PLENARY LECTURE}

Thursday, 7:30 PM Award presentations and plenary lecture by the recipient of the 1996 Award for Distinguished Contribution in Mass Spectrometry.

Conference participants will have a choice of hotels near the Convention Center, as well as in downtown Portland. There is a substantial number of rooms in the $\$ 60-\$ 80$ price range, as well as deluxe accommodations running $\$ 100-\$ 120$. The Portland Convention Bureau will coordinate room reservations. Portland has a light rail system which provides convenient transportation between downtown Portland and the Convention Center.

\section{Conference calendar:}

March 30 Deadline for payment of dues to obtain member registration rate for the conference and short courses

April 12 Deadline for receipt of advance registrations

May 11-12 ASMS Short Courses

May 12-16 Conference

\section{ASMS SHORT COURSES}

Five short courses will be offered Saturday and Sunday, May 11-12, immediately preceding the ASMS conference. The courses are as follows:

"Interpretation of Mass Spectra," organized by the Washington/Baltimore Mass Spectrometry Discussion Group

"LC/MS: The Art and the Practice," organized by Alfred L. Yergey and Robert D. Voyksner

"Practical MS/MS," organized by Jodie V. Johnson and Richard A. Yost

"Introduction to Ion Optics and SIMION," organized by David A. Dahl and Anthony D. Appelhans

"Mass Spectrometry-Approaches to Characterizing Peptides and Proteins," organized by Daniel B. Kassel, John Stults, and Pierre Thibault
These courses will be held at the Red Lion Hotel Lloyds Center. For additional information, contact ASMS, 1201 Don Diego Avenue, Santa Fe, NM 87505. Telephone: (505) 989-4517.

\section{RELATED EVENTS}

ASMS is happy to announce meetings of non-profit organizations. Please supply date, name of event, and location, along with the full address, telephone number and fax of contact person. You may also include a brief description, not to exceed one paragraph of 300 characters.

\section{6}

March 2-3

March 21-22

May $12-16$

March 30-April 2 ABRF '96: Biomolecular Techniques. An International Symposium sponsored by The Association of Biomolecular Resource Facilities, San Francisco, California. The conference includes symposia on new biotechnologyrelated techniques as well as numerous workshops and tutorials covering methodology related to analyses and/or synthesis of peptides, proteins, nucleic acids, and carbohydrates. Further details from Jean Lash, Meeting Manager, FASEB, 9650 Rockville Pike, Bethesda, MD 20814. Telephone (301) 530-7010. Fax: (301) 530-7014. Email: jlash@osmc.faseb.org.

44th ASMS Conference on Mass Spectrometry and Allied Topics, Oregon Convention Center, Portland, Oregon. Contact: ASMS, 1201 Don Diego Avenue, Santa $\mathrm{Fe}, \mathrm{NM}$ 87505. Telephone: (505) 989-4517. Fax: (505) 989-1073. 
June 16-20 NATO Advanced Research Workshop, "New Methods for the Study of Molecular Aggregates" will be at Minaki Resort International in Minaki, Ontario, Canada. The meeting will focus mainly on the investigation of noncovalent biomolecular complexes by mass spectrometry. Other emerging methods and established techniques, particularly crystallography and NMR, will also be discussed. Attendance will be limited, with preference given to those actively working in the field. Some funds are available for attendance by young researchers. For further information contact conference organizer, K. G. Standing, Physics Department, University of Manitoba, Winnipeg, MB, R3T 2N2, Canada. Telephone: (204) 474-9358. Fax: (204) 269-8489. E-m ail: standin@cc.umanitoba.ca

WWW site: http://www. physics.umanitoba.ca/tof.html

July 1-5 MASSA $96-2^{\circ}$ MS-PHARMA DAY. The annual meeting of the Division of Mass Spectrometry of the Italian Chemical Society will be held in Siena, Italy. The meeting will deal with all the aspects and applications of mass spectrometry. A session will be devoted to applications in biomedicine, biotechnology, and in the pharmaceutical field. For more information, contact: Dr. Gianluca Giogi, C.I.A.D.S., University of Siena, via P.A. Mattioli, 1053100 Siena, Italy. Phone: 39-577298925. Fax: 39-577-298927. Email: ciads@unisl.it. Circular on Internet at the site: http:// www.cineca.it / mass_spectrom /massa96/

July 14-19 The ACS Short Course, "Mass Spectrometry: Principles and Practice," offered at Michigan State University, East Lansing, MI. For further information contact: Office of Continuing Education in Washington, DC. Phone: (800) 227-5558. Fax: (202) 8726336.

August 23-24 The ACS Short Course, "Interpretation of Mass Spectra," offered at the Fall National ACS
Meeting in Orlando, FL. For further information contact: Office of Continuing Education in Washington, DC. Phone: (800) 227-5558. Fax: (202) 872-6336.

September 8-11 22nd Meeting of the British Mass Spectrometry Society, University of Wales, Swansea. For further information contact: Dr. Fred Mellon, Institute of Food Research, Norwich Laboratory, Norwich Research Park, Colney, Norwich NR4 7UA, UK. Telephone: 44-1603-255299. Fax: 441603-452578. E-mail: fred.mellon@bbsrc.ac.uk. The meeting aims to provide a forum for mass spectrometrists from a wide range of scientific disciplines and to stimulate ideas and promote discussion. The form of the meeting is under continuous review in order to keep abreast of new developments and cater to the growing and diversifying interests of mass spectrometrists. Fuller details and registration forms will be available early in 1996.

September 18-21 Desorption '96 to be held in Bornholm, Denmark. Desorption '96 is a continuation of the IFOS Symposia, the meetings in Orsay, Wangerooge, and Spikerooge and Desorption '92 and ' 94 on mass spectrometry of large organic ions. The conference will be devoted to the most recent methods for producing, mass analyzing, and detecting large organic ions. Main topics are fundamental, instrumentation, applications, and new trends in the mass spectrometric methods with emphasis on MALDI, ESI, and cluster and macromolecular impact. Further details from Mrs. P. Almqvist, Div. Ion Physics, Uppsala University, Box 535, S-751 21, Uppsala, Sweden, Phone: 4618183040. Fax: 46 18555736. E-mail: almqvist@ts1.uu.se

September 20-24 12th Asilomar Conference on Mass Spectrometry, "Elemental Mass Spectrometry," organized by Gary M. Hieftje. Asilomar Conference Center, Pacific Grove, CA. Contact: ASMS, 1201 Don Diego Avenue, Santa Fe, NM 
87505. Phone (505) 989-4517. Fax: (505) 989-1073.

September 29October 4

November 21-22

The Twenty-Third Annual Conference of the Federation of Analytical Chemistry and Spectroscopy Societies (FACSS) will be held in Kansas City, MO at the $\mathrm{H}$. Roe Bartle Convention Center. The deadline for submission of titles and a preliminary 100 word brief is March 29, 1996. For further information, please contact: FACSS, 201B Broadway Street, Frederick, MD 21701-6501. Telephone: (301) 846-4797.

November 21-22 The ACS Short Course, "Interpretation of Mass Spectra," offered at the Eastern Analytical Society meeting in Somerset, NJ. For further information contact: Office of Continuing Education in Washington, DC. Phone: (800) 227-5558. Fax: (202) 872-6336.
November 23-26 Society for Glycobiology Annual. Conference to be held in Boston, Massachusetts at the Boston Marriott Copley Place. For additional information contact: Professional Association Management, 1201 Don Diego Avenue, Santa Fe, NM 87505. Telephone: (505) 989-4735. Fax: (505) 989-1073.

November 26-28 The 7th National Symposium on Mass Spectrometry, organized by the Indian Society for Mass Spectrometry, will be held in Gwalior, India. For additional information contact: Dr. Suresh Aggarwal, Fuel Chemistry Division, Bhabha Atomic Research Center, Bombay 400085 , or Dr. G. Sudhakar Reddy, The University of Michigan, OSEH, 1655 Dean Road, Ann Arbor, MI 48109. Phone: (313) 763-4615. Fax: (313) 763-4600. 